Doi: HTTPS://DOI.ORG/10.23910/IJEP/2018.5.3.0218

\title{
Effect of Growth Regulators and Micronutrients Spray on Chemical Parameters of Litchi (Litchi chinensis Sonn.) cv. Calcuttia
}

\author{
Vikramaditya Priyadarshi ${ }^{1}$, Debashish Hota $^{1 *}$ and Ajay Kumar Karna
}

\author{
${ }^{1}$ Dept. of Fruit Science, Dr. Y. S. Parmar University of Horticulture and Forestry, Nauni, Solan (173 230), India \\ ${ }^{2}$ Dept. of Horticulture, College of Agriculture, Junagadh Agricultural University, Junagadh, Gujarat (362 001), India
}

\section{Corresponding Author}

Debashish Hota

e-mail:dhota3@gmail.com

\author{
Article History \\ Article ID: IJEP0218 \\ Received in $25^{\text {th }}$ October, 2017 \\ Received in revised form $05^{\text {th }}$ August, 2018 \\ Accepted in final form $17^{\text {th }}$ August, 2018
}

\begin{abstract}
Being one of the finest fruit, litchi still need a major attention toward the problems like irregular flowering, poor fruit set, heavy fruit drop, low yield, fruit cracking and poor quality to meet the growing demand of national and international market. Bio-regulators and micro-nutrient are being used by the growers to increase the yield by improving the yield attributing parameters. The present experiment was laid out at the Regional Horticulture Research and Training Station, Dhaulakuan, Dr. Yashwant Singh Parmar University of Horticulture and Forestry, NauniSolan (HP). Keeping the objective to increase the yield, in the recent studies; trees were subjected to 19 treatments viz. GA, $\mathrm{CPPU}_{3^{\prime}} \mathrm{ZnSO}_{4^{\prime}}$ Boric acid, $\mathrm{GA}_{3}+\mathrm{CPPU}$, Boric acid+ZnSO $\mathrm{Zn}_{4}$ and control. The plants treated with $\mathrm{ZnSO}_{4}(0.75 \%)$ recorded highest total soluble solid (20.40 $\left.{ }^{\circ} \mathrm{B}\right)$ and highest non-reducing sugars (2.98\%). Application of Boric acid $(0.75 \%)$ recorded maximum reducing sugars $(11.14 \%)$. Foliar spray of boric acid $(0.5 \%)+\mathrm{ZnSO}_{4}(0.5 \%)$ significantly increases the total sugar content $(13.79 \%)$ and decreased the titratable acidity $(0.32 \%)$ of fruits.
\end{abstract}

Keywords: Bio regulator, boric acid, $\mathrm{CPPU}, \mathrm{GA}_{3}$, litchi, $\mathrm{ZnSO}_{4}$

\section{Introduction}

Litchi recognized as "Queen of the fruits" is the most important subtropical fruit crop which belongs to family Sapindaceae. It is a subtropical evergreen tree and is adapted to the areas of cool dry winters and warm wet summers. It usually likes low elevations but can be grown up to an altitude of 800 meters above mean sea level with varying degree of success. Due to its exact climatic requirements, its cultivation is restricted to few states in our country. Being one of the finest fruit, litchi still need a major attention towards the problem like irregular flowering, poor fruit set, heavy fruit drop, low yield, fruit cracking and poor quality to meet the growing demand of national and international market.

In India 5,83,400 mt of litchi is produced annually from 92,100 ha area. (Anonymous, 2017). In Himachal Pradesh, it is being cultivated commercially in Kangra, Sirmour, Bilaspur and Una districts, occupying an area of 5,673 ha and production $5,469 \mathrm{mt}$, out of which maximum area and production is under Kangra district (Anonymous, 2017). Recent studies on fruit physiology and nutrition have focussed attention on significance of plant growth regulators and micronutrients in overcoming the problems by modifying various physiological and metabolic processes.

Plant growth regulators have been used for many years to alter the behaviour of fruit or fruit plants for the economic benefits. It is also reported that growth substances like Gibberellic acid, NAA and CPPU have great influence on litchi. Hota et al. (2017 a, b, c, d, e and f) conducted a research trial in 26-year-old apricot cv. New Castle by using CPPU and NATCA at Department of Fruit Science, Dr. Y.S. Parmar University of Horticulture and Forestry during the years 2015 and 2016. He found that CPPU at petal fall stage increases the tree height, tree spread, tree volume, annual shoot growth, trunk girth, leaf area, fruit length, fruit diameter, fruit weight, fruit volume, pulp weight, stone weight and pulp to stone ratio, fruit firmness and yield significantly then the control in both the years. CPPU stimulated cell expansion in the pericarp sufficiently to explain the measured increase in total fruit volume.

Micronutrients plays specific role in improving the growth, yield and quality of litchi even though these elements are needed in small quantities. Boron and Zinc is essentially required for growth and development in litchi and is involved in diverse range of enzyme system. Considering the importance of plant growth regulators and micronutrients in fruit production, the present investigation is carried out on $\mathrm{cv}$. Calcuttia to observe the effect of Gibberellic acid (GA $\left.A_{3}\right), C P P U$ (N-(2-Chloro-4-pyridyl)-N-phenylurea), Boric acid and $\mathrm{ZnSO}_{4}$ 
(Zinc sulphate) on chemical composition of litchi.

\section{Materials and Methods}

The experiment was conducted on 12-year-old trees of litchi cultivar Calcuttia, at Regional Horticulture Research and Training Centre, Dhaulakuan, Dr. Yashwant Singh Parmar University of Horticulture and Forestry, Nauni Solan (Himachal Pradesh). Fifty-seven uniform bearing trees with uniform vigour and size, planted at a spacing of $8 \times 8 \mathrm{~m}^{2}$ were selected for study. The required amount of each plant growth regulators was taken and final volume was made to one litre with water to serve as stock solution. Two to three drops of surfactant (Teepol) per litre of solution was added to reduce surface tension and to facilitate the absorption of solution. Spraying was done with the help of foot sprayer, till the leaves were wet and droplets of solution started trickling down, on clear and calm day during the morning hours at fruit set stage and repeated after one weak, during 2014 and 2015. The experiment consisted of 19 treatments (Table 1 ) and 3 replications with Randomized Block Design. The data generated from these investigations were appropriately computed, tabulated and analyzed by applying Randomized

Table 1: Different treatments and their concentrations used in the experiment

\begin{tabular}{lll}
\hline Treatments & Chemical & Concentration \\
\hline $\mathrm{T}_{1}$ & $\mathrm{GA}_{3}$ & $25 \mathrm{ppm}$ \\
$\mathrm{T}_{2}$ & $\mathrm{GA}_{3}$ & $50 \mathrm{ppm}$ \\
$\mathrm{T}_{3}$ & $\mathrm{GA}_{3}$ & $75 \mathrm{ppm}$ \\
$\mathrm{T}_{4}$ & CPPU & $5 \mathrm{ppm}$ \\
$\mathrm{T}_{5}$ & CPPU & $10 \mathrm{ppm}$ \\
$\mathrm{T}_{6}$ & CPPU & $15 \mathrm{ppm}$ \\
$\mathrm{T}_{7}$ & ZnSO & $0.25 \%$ \\
$\mathrm{~T}_{8}$ & ZnSO & \\
$\mathrm{T}_{9}$ & ZnSO & \\
$\mathrm{T}_{10}$ & Boric acid & $0.50 \%$ \\
$\mathrm{~T}_{11}$ & Boric acid & $0.75 \%$ \\
$\mathrm{~T}_{12}$ & Boric acid & $0.75 \%$ \\
$\mathrm{~T}_{13}$ & GA3+CPPU & $25 \mathrm{ppm}+5 \mathrm{ppm}$ \\
$\mathrm{T}_{14}$ & GA3+CPPU & $50 \mathrm{ppm}+5 \mathrm{ppm}$ \\
$\mathrm{T}_{15}$ & GA3+CPPU & $75 \mathrm{ppm}+5 \mathrm{ppm}$ \\
$\mathrm{T}_{16}$ & Boric acid+ZnSO & $0.25 \%+0.50 \%$ \\
$\mathrm{~T}_{17}$ & Boric acid+ZnSO & $0.50 \%+0.50 \%$ \\
$\mathrm{~T}_{18}$ & Boric acid+ZnSO & $0.75 \%+0.50 \%$ \\
$\mathrm{~T}_{19}$ & Control & Water spray \\
\hline
\end{tabular}

Block Design (RBD). The level of significance was tested for different variables at $5 \%$ level of significance.

2.1. Total soluble solids (TSS)
The total soluble solids of the fruit juice were determined with Erma-Hand refractometer ( 0 to $\left.32^{\circ} \mathrm{B}\right)$. The refractometer was calibrated with distilled water before use. The readings were recorded for each sample by putting a drop of juice on the prism and value was recorded. A temperature correction was applied when it was above or below $20^{\circ} \mathrm{C}$ and the readings were expressed in degree Brix ( $\left.{ }^{\circ} \mathrm{B}\right)$ (AOAC, 1980).

\subsection{Titratable acidity}

Twenty-five grams of fruit was crushed and the volume made to $250 \mathrm{ml}$ in a volumetric flask by adding distilled water. Out of it, $50 \mathrm{ml}$ extract (solution) was taken for the estimation of acidity and rest for determining total and reducing sugars. Ten $\mathrm{ml}$ of juice extract was titrated against N/10 NaOH using phenolphthalein as indicator. Change of the solution colour to light pink indicated the end point. The total titratable acidity was then, calculated in terms of malic acid and expressed in percentage. (Ranganna, 1977).

Titratable acidity $(\%)=($ Titre $\times$ Normality of $\mathrm{NaOH} \times$ Volume madexEquivalent weight of acid $\times 100$ )/(Volume of sample taken $\times$ Weight or volume of aliquot taken $\times 1000$ )

\subsection{Total sugar}

The remaining $200 \mathrm{ml}$ extract was taken in a $250 \mathrm{ml}$ volumetric flask and the volume was again made to $250 \mathrm{ml}$., to this 250 $\mathrm{ml}$ solution, $5 \mathrm{ml}$ of $20 \%$ lead acetate was added. After 5-10 minutes, $5 \mathrm{ml}$ of 10 per cent sodium oxalate was added to precipitate the excess of lead acetate and filtered. Fifty $\mathrm{ml}$ of the filtrate was taken and hydrolyzed by adding concentrated hydrochloride acid $(\mathrm{HCl})$ and allowed it to stand overnight for complete reaction. The excess of $\mathrm{HCl}$ was neutralized with saturated $\mathrm{NaOH}$ solution the next day. The hydrolyzed aliquot was then taken in a burette and titrated against boiling solution containing $5 \mathrm{ml}$ each of Fehling $\mathrm{A}$ and $\mathrm{B}$ using methylene blue as an indicator. The end point was indicated by the appearance of brick red colour and the total sugars were worked out as per cent of fresh weight of the berry pulp (AOAC, 1980).

$$
\begin{aligned}
& \text { Total sugar }(\%)=\frac{{ }^{*} \text { Factor } \times \text { Dilution } \times \text { Dilution }}{\text { Titre value } \times \text { Weight or }} \\
& \text { Volume of sample taken }
\end{aligned}
$$

\subsection{Reducing sugars}

For the estimation of reducing sugar, $5 \mathrm{ml}$ of each Fehling solution A and Fehling solution B was taken in a beaker and $50 \mathrm{ml}$ of distilled water was added to it. It was then boiled for about 10 minutes and then 2-3 drops of Methylene blue indicator was added and titrated against filtrate obtained. The beaker was regularly shaken and the end point of filtrate used was noted upon obtaining a brick red colour. Reducing sugars were estimated as per cent reducing sugar content and calculated as per formula given.

Reducing sugars $(\%)=\frac{{ }^{*} \text { Factor } \times \text { Dilution }}{\text { Titre value } \times \text { Weight }} \times 100$ 
${ }^{*}$ Factor $=0.05$

\subsection{Non-reducing sugars}

The percentage of non-reducing sugars in the juice was determined by subtracting the reducing sugars from the total sugars as invert sugars and multiplying by the factor 0.95 and expressed as percentage of juice weight (AOAC, 1980).

Non-reducing sugar $(\%)=($ Total sugars-Reducing sugars $) \times 0.95$

\section{Results and Discussion}

\subsection{Total soluble solids}

The observations on effect of growth regulators and micronutrient spray on total soluble solids in litchi are given in Figure 1. It is evident from the figure that all the growth regulators and micronutrients increased the total soluble solids as compared to control. The pooled values during the year 2013-14 and 2014-15 showed that the maximum total soluble solids $\left(20.40^{\circ} \mathrm{B}\right)$ were obtained with $\mathrm{T}_{9}\left(\mathrm{ZnSO}_{4} 0.75 \%\right)$ treatment which is statistically at par with $\mathrm{T}_{11}, \mathrm{~T}_{16}, \mathrm{~T}_{8^{\prime}}, \mathrm{T}_{4^{\prime}}, \mathrm{T}_{12}$,

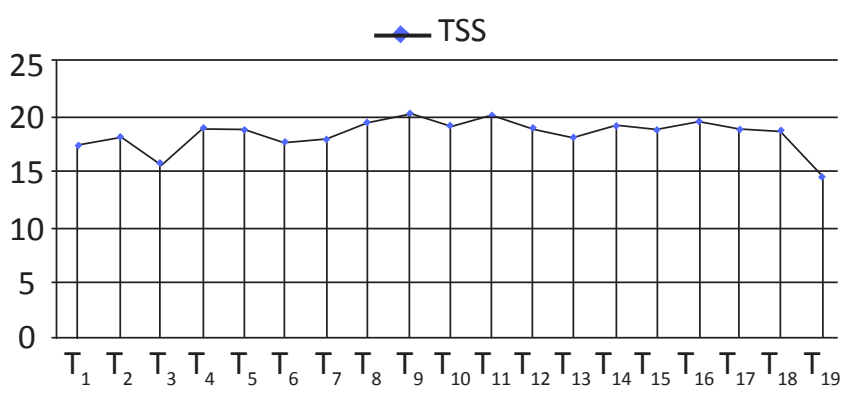

Figure 1: Effect of growth regulators and micronutrients spray on TSS ( ${ }^{\circ} \mathrm{Brix}$ ) in litchi

$\mathrm{T}_{5}, \mathrm{~T}_{10}, \mathrm{~T}_{14}, \mathrm{~T}_{15}, \mathrm{~T}_{17}$ and $\mathrm{T}_{18}$. The minimum total soluble solids $\left(14.20^{\circ} \mathrm{B}\right)$ were observed in $\mathrm{T}_{19}$ (Control).

Zinc is an important micronutrient associated especially with several enzymatic activities and growth regulators biosynthesis in all photosynthetic plants (Ved et al., 2002). It is considered a functional, structural or regulatory factor of a large number of enzymes (Bowler et al., 1994). Increase in TSS content with these micronutrients may be attributed to the quick metabolic transformation of starch and pectin into soluble compounds and rapid translocation of sugars from leaves to developing fruits (Brahmachari and Rani, 2001). The results of the present study are in agreement with the findings of Jain et al. (1985); Brahmachari and Rani (2001); Sharma et al. (2005); Singh (2009); Singh and Kaur (2016) who reported similar type of TSS encouragement in litchi with the application of micronutrients.

\subsection{Total sugars}

The perusal of data presented in Figure 2 reveals that the growth regulators and micronutrients treatment exhibited significant effect on total sugars and the values varied within very narrow range. The pooled data of the year 2013-14 and 2014-15 showed that the maximum total sugars (13.79\%) were obtained with $\mathrm{T}_{17}$ (Boric acid $0.5 \%+\mathrm{ZnSO}_{4}$ 0.5\%)

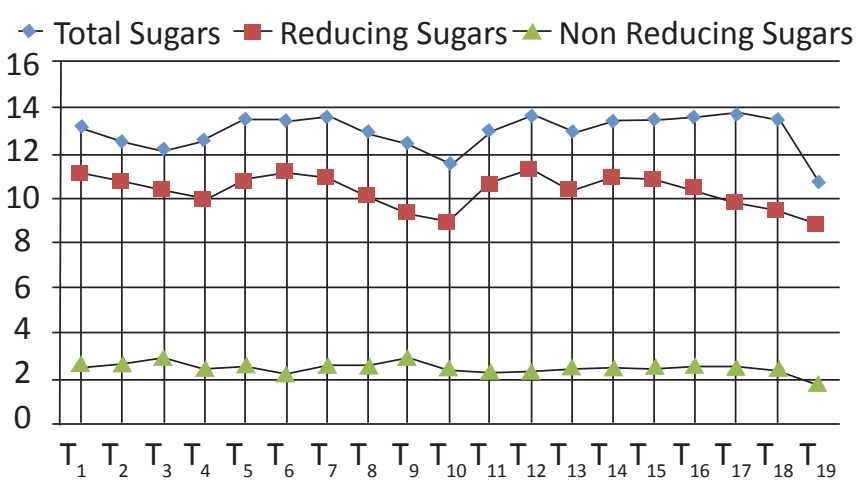

Figure 2 : Effect of growth regulators and micronutrients spray on Total Sugars (\%), Reducing and Non-Reducing sugars (\%) in litchi

treatment was superior to all other treatments which recorded significantly higher total sugars than control. Other treatment like $\mathrm{T}_{15}$ and $\mathrm{T}_{16}$ are statistically at par with $\mathrm{T}_{17}$. The minimum sugars $\left(10.76 \%\right.$ ) were observed with $\mathrm{T}_{19}$ (Control).

The improvement in the total sugars might be due to better translocation of sugars from leaves to developing fruits. The enhancement in quality of fruit could be due to the catalytic action of micronutrients particularly at higher concentration. Hence, the foliar application of micronutrients quickly increased the uptake of macronutrients in the tissues and organs of the litchi plants, decreased the nutritional deficiencies and improved the fruit quality. These results are in closed conformity with the findings of Rawat et al. (2010) and Yadav et al. (2011) in guava fruits and Tanuja et al. (2016) in Pomegranate.

\subsection{Reducing sugars}

The data pertaining to the effect of growth regulators and micronutrients treatment on reducing sugars content of litchi fruits are depicted in Figure 2. The reducing sugars varied from 8.87 to $11.14 \%$. The pooled value of the year $2013-14$ and 2014-15 showed that the maximum reducing sugars (11.14\%) were observed with $\mathrm{T}_{12}$ (Boric acid 0.75\%), which was statistically at par with $\mathrm{T}_{6}$ and $\mathrm{T}_{1}$. Lowest reducing sugars $(8.87 \%)$ were recorded in control fruits.

The above findings are supported by Gurung et al. (2016) in mandarin.The increase in the sugar content might be due to the more rapid translocation of sugars from leaves to developing fruits. Boron facilitated sugar transport within the plant. It was also reported that borate reacted with sugar to form a sugar-borate complex, which is easier to transverse membrane. Boron acted as a switcher in the degradation of glucose either by glycolysis or by pentose sugar path way. These results also collaborate the findings of Sachindra et al. (2012); Haq et al. (2013) in litchi, Singh (2009); Kaur (2017) in litchi cv. Dehradun, Kumar et al. (2017) in litchi cv Early Large Red and Tirupathahiah et al. (2017) in Sapota cv Kalipatti.

\subsection{Non-reducing sugars}

The data pertaining to the effect of growth regulators and 
micronutrients treatment on non-reducing sugars content of litchi fruit are presented in Figure 2. The pooled analysis of data during the year 2013-14 and 2014-15 indicated that values of different growth regulators and micronutrients treatment on non-reducing sugars differed significantly. The maximum non-reducing sugars $(2.98 \%)$ were observed with $\mathrm{T}_{9}$ $\left(\mathrm{ZnSO}_{4} 0.75 \%\right)$ treatment which was significantly higher than the minimum value $(1.77 \%)$ recorded in control trees. The $\mathrm{T}_{3}$ treatment was found to be statistically at par with $\mathrm{T}_{9}$.

The improved effect of zinc on fruit quality of Valencia orange might be due to the fact that zinc play an active role in production of auxin in plant (Alloway, 2008), and its effect on starch metabolism (Hafez et al., 2007), biological processes such as photosynthesis reaction and carbohydrate biosynthesis (Yamdagni et al., 1979), nucleic acid metabolism and cell division as well as protein which led to more accumulation of metabolites in fruit (Badu and singh, 2001; Dickinson et al., 2003). Also, zinc play an important role in the activities various enzymes involved in this biochemical reaction, which facilitates and increases buildup of organic compounds (Alloway, 2008) subsequently, improved fruit quality of Litchi. The obtained results of zinc are in agreement with the findings of Hanafy Ahmed et al. (2012), Abd El-Motty and Orabi (2014) and Amro and Salama (2015) in sweet orange.

\subsection{Titratable acidity}

Data on the effect of different treatments on titratable acidity are given in Figure 3. It reveals significant differences among different growth regulators and micronutrients treatment on titratable acidity. In pooled data of the year 2013-14 and 2014-15, the maximum acidity $(1.37 \%)$ was recorded with $\mathrm{T}_{4}$ (CPPU 5 ppm), whereas the minimum acidity $(0.32 \%)$ was noted with $\mathrm{T}_{17}$ (Boric acid $(0.50 \%)+\mathrm{ZnSO}_{4}(0.50 \%)$, which was lowest among all the treatments. The treatment $\mathrm{T}_{16}$ and $\mathrm{T}_{18}$

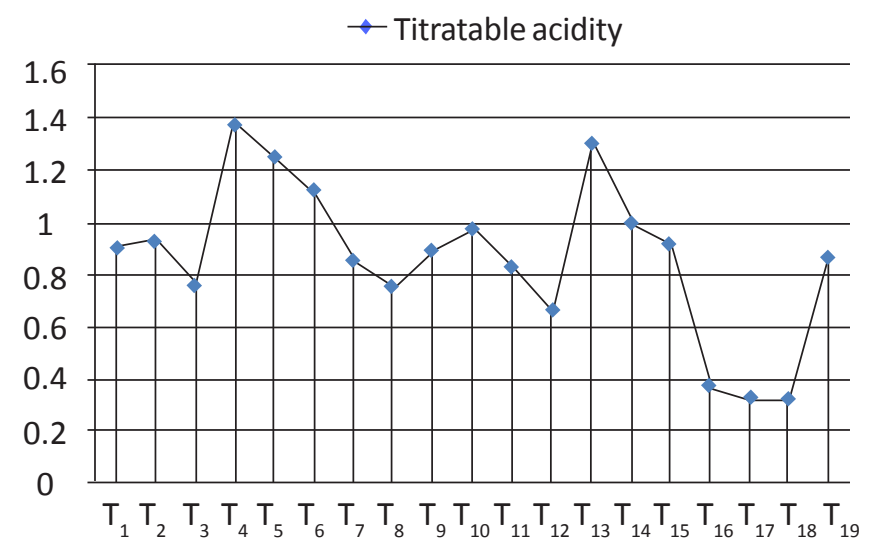

Figure 3: Effect of growth regulators and micronutrients spray on Titratable acidity (\%) in litchi

was found to be statistically at par with $\mathrm{T}_{17}$.

Boron and zinc sprays being highly helpful in the process of photosynthesis which laid to accumulation of carbohydrate which ultimately improved the fruits quality in fact zinc works as a stimulant for amino acid synthesis and helps in the process of photosynthesis (Singh et al., 2012). In the previous observations we have seen that Boron and Zinc helps in sugar accumulation in the fruit from the source to sink. This may be the reason for decrease in the acidity of litchi fruit. The above findings are supported by Anees et al. (2011); Baiea et al. (2015) in mango; Singh and Kaur (2016) in litchi.

\section{Conclusion}

Various pre-harvest applications of bio regulators have been experimented on litchi to increase the qualitative parameter. In the above research, application of boron and zinc or their combinations has greater significance. Both the micro nutrient plays an important role in plant metabolism and hence increases the chemical parameter like TSS $\left(20.40^{\circ} \mathrm{Brix}\right)$, total sugars $(13.79 \%)$, reducing sugars $(11.14 \%)$, non-reducing sugars $(2.98 \%)$ and decreases the titratable acidity $(0.32 \%)$ of the fruit. From the above research, it may be concluded that application of Boric Acid (50\%)+Zinc Sulphate (50\%) at fruit set stage and again one week after fruit set increases the chemical parameters of litchi cv Calcuttia.

\section{References}

A.O.A.C., 1980. Official Methods of Analytical Chemists, $13^{\text {th }}$ ed. (Hortwitz, W. (Ed.), Association of Official Chemists33, 617-623.

Abd El-Motty, E.Z., Orabi, S.A., 2014. The beneficial effects of using zinc, yeast and selenium on yield, fruit quality and antioxidant defence systems in Navel orange trees grown under newly reclaimed sandy soil. Journal of Applied Sciences Research 9(10), 6487-6497.

Alloway, B.J., 2008. Zinc in soils and crop nutrition. International Zinc Association Brussel, Belgium.

Amro., Salama, S.M., 2015. Effect of algae extract and zinc sulfate foliar spray on production and fruit quality of orange tree cv. valencia. Journal of Agriculture and Veterinary Science 8(9), 51-62.

Anees, M., Tahir, F.M., Shahzad, J., Mahmood, N., 2011. Effect of foliar application of micronutrients on the quality of mango (Mangifera indica L.) cv. Dasehari fruit. Mycopath 9(1), 25-28.

Anonymous, 2012. State department of horticulture, Government of Himachal Pradesh. Available from: http://www.hpagrisnet.gov.in/hpagris/Horticulture/ Default.aspx?SitelD=5\&PagelD=1219

Anonymous, 2017. Area, Production and Yield of Horticultural Crops. In: Horticultural statistics at a glance 2017. Horticulture Statistics Division, Department of Agriculture, Cooperation \& Farmers Welfare, Ministry of Agriculture \& Farmers Welfare Government of India. p- 147. Available from: http://nhb.gov.in/statistics/ Publication/Horticulture\%20At\%20a\%20Glance\%20 2017\%20for\%20net\%20uplod\%20(2).pdf

Baiea, M.H.M., El-Badawy, H.E.M., El-Guioshy, S.F., 2015. Effect of potassium, zinc and boron on growth, yield and fruit quality of keitt mango trees. Research Journal of Pharmaceutical, Biological and Chemical Sciences 6(4), 800-812. 
Bowler, C., Vancamp, W., Vanmontagu, M., Inze, D., 1994. Superoxide-dismutase in plants. Critical Reviews in Plant Sciences 13(3), 199-218.

Brahmachari, V.S., Rani, R., 2001. Effect of growth substances on fruit drop, yield and physico-chemical composition of litchi fruits. Prog Hort., 32, 50-55.

Dickinson, K., O’Brien, J., Voet, L., Edwards, T., 2003. Metalosate "zinc in plant nutrition". Albion. 4(2), 1-4.

Hafez, M.O., El- Metwally, I.M., 2007. Efficiency of zinc and potassium sprays alone or in combination with some weed control treatments on weeds growth, yield and fruit quality of Washington navel orange orchards. Journal of Applied Sciences Research 3(7), 613-621.

Hanafy Ahmed, A.H., Khalil, K., Abd El-Rahman, A.M., Hamed, N.A.M., 2012. Effect of zinc, tryptophan and indole acetic acid on growth, yield and chemical composition of Valencia orange trees. Journal of Applied Sciences Research 8(2), 901-914.

Haq, I., Rab, A., Sajid, M., 2013. Foliar application of calcium chloride and borax enhance the fruit quality of litchi cultivars. The Journal of Animal and Plant Sciences 23(5), 1385-1390.

Hota, D., Sharma, D.P., Bhoyar, M.G., 2017b. Analysis of vegetative growth by spraying of forchlorfenuron and $\mathrm{N}$-acetyl thiazolidine 4-carboxylic acid on of apricot (Prunus armeniaca L.) cv. New Castle. International Journal of Chemical Studies 5(5), 2182-2185.

Hota, D., Sharma, D.P., Sharma, N., 2017a. Effect of Forchlorfenuron and N-Acetyl Thiazolidine 4-Carboxylic Acid on vegetative growth and fruit set of Apricot (Prunus armeniaca L.) cv. New Castle. Journal of Pharmacognosy and Phytochemistry 6(2), 279-282.

Hota, D., Sharma, D.P., Singh, N., 2017e. Effect of Forchlorfenuron and N-Acetyl Thiazolidine 4-Carboxylic Acid on Fruit Drop of Apricot (Prunus armeniaca L.) cV. New Castle. International Journal of Pure \& Applied Bioscience 5(5), 1123-1127.

Hota, D., Sharma, D.P., Prasad, H., Chauhan, A., 2017f. Effect of Forchlorfenuron and N-Acetyl Thiazolidine 4-Carboxylic Acid on physico-chemical parameter of Apricot (Prunus armeniaca L.) cv. New Castle. Bulletin of Environment, Pharmacology and Life Sciences 6(5), 224-228.

Hota, D., Sharma, D.P., Sharma, N., Mishra, G., Solanki, S.P.S., Priyadarshi, V., 2017c. Effect of forchlorfenuron and N-Acetyl thiazolidine 4-carboxylic acid on size and yield of apricot (Prunus armeniaca L.) cv. New Castle. International Journal of Current Microbiology and Applied Sciences 6(9), 1852-1860.

Hota, D., Sharma, D.P., Sharma, S., Singh, N., 2017d. Effect of forchlorfenuron and n-acetyl thiazolidine 4-carboxylic acid on physical parameter of apricot (Prunus armeniaca L.) cv. new castle. Chemical Science Review and Letters 6(24), 2408-2412.

Gurung, S., Mahato, S.K., Suresh, C.P., Chetrri, B., 2016. Impact of foliar application of growth regulators and micronutrients on the performance of darjeeling mandarin. American Journal of Experimental Agriculture
12(4), 1-7.

Jain, B.P., Das, S.R., Verma, S.K., 1985. Effect of growth substances and minor elements on the synthesis of major chemical constituents of Litchi. Haryana Journal of Horticultural Sciences 14, 1-3.

Kaur, S., 2017. Effect of micronutrients and plant growth regulators on fruit set, fruit retention, yield and quality attributes in litchi cultivar Dehradun. Chemical Science Review and Letters 6(22), 982-986.

Kumar, D., Mohammed, S., Kathwal, R., Chander, S., 2017. Effect of different nutrient sprays on growth, fruit yield and quality of litchi (Litchi chinensis Sonn.) cv. Early Large Red. Research on Crops 18(1), 61-65.

Ranganna, S., 1977. Manual of analysis of fruits and vegetable products. Tata Mcgraw Hill, New Delhi.

Rawat, V., Tomar, Y.K., Rawat, J.M.S., 2010. Influence of foliar application of micronutrients on the fruit quality of guava cv. Lucknow-49. Journal of Hill Agriculture 1(I), 63-66.

Sachindra, N., Kumar, M., Ojha, R.K., Jhak, K., 2012. Yield and physico-chemical properties of litchi fruits as affected by different rates of pruning and chemical spray. Progressive Hort 44, 166-169.

Sharma, P., Singh, A.K., Sharma, R.M., 2005. Effect of plant bio-regulators (PBRs) and micronutrients on fruit set and quality of litchi cv. Dehradun. Indian Journal of Horticulture 62, 24-26.

Singh, N., Kaur, A., 2016. Response of quality attributes of litchi cv. Dehradun to foliar application of zinc and boron. International journal of current Research 4(10), 339-342.

Singh, P.C., Gangwar, R.S., Singh, V.K., 2012. Response of boron, zinc and copper on quality of anola fruits cV. banarasi. Hort. Flora Research Spectrum 1(1), 89-90.

Singh, P., 2009. Effect of chemicals and pgr's on flowering, fruit set, fruit retention and quality attributes in litchi cv. Dehradun. M.Sc. Thesis GNDU Amritsar.

Tanuja., Rana, D.K., Rawat, S.S., 2016. Effect of foliar application of zinc and boron on yield and quality of pomegranate (Punica granatum L.) cv. Ganesh under subtropical conditions of Garhwal hills. HortFlora Res. Spectrum 5(1), 61-64.

Tirupathahiah, G., Shirol, A.M., Naik, N., Venugopal, U., Sampath, P.M., 2017. Effect of micronutrients on postharvest quality and shelf life of sapotacv. Kalipatti. International journal of agriculture sciences 9(14), 4084-4086.

Ved, R., Mishra, S.K., Upadhyay, R.M., 2002. Effects of sulphur, zinc and biofertilizeres on the quality characteristics of mung bean. Indian Journal of Pulses Research 2, 139141.

Yadav, H.C., Yadav, A.L., Yadav, D.K., Yadav, P.K., 2011. Effect of foliar application of micro-nutrients and $\mathrm{GA}_{3}$ on yield and quality of rainy season guava (Psidium guajava L.) cv. L-49. Plant Arch. 11 (1), 147-149.

Yamdagni, R., Singh, D., Jindal, P.C., 1979. A note on effect of boron sprays on quality of grapes cv. Thompson seedless. Progressive-Horticulture 11(1), 35-36. 